DOI https://doi.org/10.18551/rjoas.2018-06.26

\title{
EFFECT OF COMPETENCE AND EFFORT OF AUDITORS TO AUDITOR PERFORMANCE TO THE USE OF INFORMATION TECHNOLOGY AS VARIABLE MEDIATION
}

\author{
Aini Fifi Aprilia Nurul \\ Researcher, Indonesia \\ E-mail: fifi.aprilia.fa@gmail.com
}

\begin{abstract}
The pupose of this study is to determine whether there is influence between competence and effort to auditor performance with information technology usage as mediation variables. Objects in this study are the auditor who work in Kantor Akuntan Publik. Data were collected by questionnaire survey method. Primary data generated as much as 61 questionnaires can be processed using the Partial Least Square. Evaluation models in PLS is done by evaluating the outer and inner models. The results of this study indicate that the auditor's competence and effort had a positive influence on the performance of auditors, but the use of information technology is not a mediating variable between competence, effort auditor to auditor performance.
\end{abstract}

\section{KEY WORDS}

Competence, effort auditor, information technology, auditor performance.

Moral hazard problem often occurs between the management and the principal (shareholder) where management only the pursuit of the interests of himself at the expense of the principal, causing the agency conflict. One way to reduce the consequences and the costs associated with moral hazard is to hire an independent external third party that is a public accountant to audit books, records, and financial statements, thereby reducing asymmetric information between the agent of the company and its principals.

Public Accountant Services are services used in economic decision-making and influence widely in the era of globalization which has an important role in supporting the national economy healthy and efficient so that the transparency and quality of financial information increases (Law No. 5 of 2011). Therefore public accountant must carry out their duties in accordance with the standards and code of professional conduct set professional organizations as well as follow the rules or regulations in force and have an attitude of independence.

However, with the discovery of accounting scandals that occurred Enron Corporation, WorldCom and on several public companies in the United States has caused a crisis of public confidence in the quality of the resulting audit by public accountants (Duff, 2004). The accounting scandal became a global issue because it involves one of the largest Kantor Akuntan Publik The big-five accounting firm Arthur Andersen namely (Choi, et al., 2010).

Not only abroad, some Kantor Akuntan Publik (KAP) and Public Accountants in Indonesia was also found guilty of violation of standard audit and sanctioned by the Minister of Finance of the Republic of Indonesia. Non-compliance is a violation of the provisions Pasa1 25 paragraph (2) c of Undang-Undang 5 of 2011 on Public Accountant and pasal 44 of PMK Number 17 / PMK.01/2008 concerning Public Accountant Services which resulted in the freezing of public accountant's permit and public accountant's license.

Based on audit cases above, caused a decline in public confidence in the profession of public accounting for the low quality of the audit was doing. Quality audits as a possibility (probability) that the auditor during the audit the financial statements can detect and report a possible violation of the client's accounting system. Technical ability indepensi auditor and the auditor can find the probability of an offense (De Angelo, 1981). Violations of the Standards on Auditing (SA) resulting lack mainstay of financial reporting information so as to 
produce audit reports that are not qualified. Therefore, the performance of auditors asindependent external parties questioned.

The challenges facing auditors today is how to maintain the quality of the audit (audit quality) in the middle of the business environment and information technology are changing so fast. To improve the quality of implementation aduit, pressures on audit profession will emerge, either from the internal environment of KAP and the rules of standard setters.

Auditors need to master an understanding of the technology, the Internal Control (IC) and the Information System (IS) adopted by KAP where she worked. In order to facilitate the completion of the audit, each KAP have different policies on technology and information systems it uses.

As an agency or organization, the Firm also helped implement information technology systems in its work. Application or adoUITon of information technology systems aims to bring efficiency and effectiveness in the performance of auditors. At a Kantor Akuntan Publik ,auditor or the auditor's staff are required to master information technology or information systems adopted by the previous KAP.

Computer-Assisted Audit Tools And Techniques (CAATTs) has been considered as the main technology applications for auditor (Coderre, 2009). CAATTs normally used for audit control of the application (Hall, 2010). CAATTs integrate data from multiple systems and databases and facilitate the analysis to achieve the objectives of the audit.CAATTs also be used to write scripts to perform automated audits and achieve the goal of auditing and continuous monitoring (Sun, 2012).

After KAP applying information technology used, the audit team should develop an audit plan, identifying the data needed, determine how to properly analyze the data, and then provide the right advice to management. This process relies heavily on professional judgment, knowledge, and skills of auditors (Coderre, 2009). To use CAATTs in auditing computers, auditors should have knowledge of auditing and CAATTs. With the competency to improve the performance of auditors. This has been proven by research conducted by Hsien Wu, et al. (2017) that the competence of auditors positive effect on the performance of auditors. In addition to competence, effort auditor also has an influence on the performance of auditors. This is in line with research conducted by Bonner (1994) that kCapacity of the auditor to address the different environments and makes the quality of judgment depends on effort (effort) of their own to improve).

In this study, subjects were sampled are auditors who work in Kantor Akuntan Publik (KAP) in Surabaya. This study aims to determine whether there is influence between Competence And Effort Against Auditor Auditor Performance With Information Technology Usage As Mediation Variables.

\section{LITERATURE REVIEW}

Goal-Setting Theory. Goal setting theory is a cognitive motivation theory originally developed from the idea of Locke (1968) of human action in specific work situations. The basic idea of this Locke refers to what Aristotle said "final causality", namely that the action was caused on purpose (Locke, 1996). Human intentions (human conscious intentions) as a goals, and behavior or human action is one pendent proposition underlying this theory. Term goals in this theory shows on an expression of interest, the object or action to be achieved person (Latham and Locke, 1990).

Locke (1997) suggested that the main source of motivation is the intention to achieve a goal. That is, the purpose of an auditor told what to do and how much effort should be spent. The evidence strongly supports the value of interest so that they can said that the improved performance is due to a special purpose, a higher performance resulting from difficult goals than younger goals, and feedback than no feedback, Specific goals showed levels higher yields than general purpose "do your best". The specificity of the goal itself seems to act as an internal stimulus.

Competence. Competence as the knowledge, skills, attitudes and behaviors that characterize and successful performance in the specific context (Crackin \& Carol, 1998). 
Competence is the personal aspects of a worker who allows him to achieve superior performance (Loma Dictionary, 1998).

A competent person capable of resolving the problem better than others. A challenge and the problem is seen as a means to an end by Individuals like this.

Spencer and Spencer (1993) shows that the competence consists of the following attributes: motives, traits, self-concepts, knowledge, and skills. Motif, nature, and selfconcept is the core aspects of personality are striking and difficult to grow through training. Instead, the skills and knowledge that is striking and easy to grow through training. As a result, they are easier to evaluate.

One element of competence that is self-efficacy. Bandura (1993) states that Selfefficacy is a person's belief that he can perform a task at a certain level, affecting private activities towards the achievement of objectives.

Wang et al. (2004) reported that coordinate and integrate three core competencies of marketing, technology, and integrative competence can improve work performance. Previous studies also showed that the competence of a significant effect on work performance (Levenson et al., 2006). This is supported also by Zenita et al., (2015) and Afifah et al., (2015) that self-efficacy positively and significantly affects the performance of auditors. Iskandar \& Sanusi (2011) also showed that better performance generated by auditors with a high degree of self-efficacy compared with auditors who have a low self-efficacy.

From the above it can be concluded that with the competencies both in terms of knowledge, self-efficacy, good skills possessed auditor can improve work performance auditor. Therefore, this study proposes Hypothesis 1 as follows:

$\mathrm{H} 1$ : Competence positive effect on the performance of auditors.

Effort Auditors. Social cognitive theory Robbins (2006) states that the social cognitive theory establishes a framework for the understanding, prediction and responsibilities of human behavior. This theory identifies human behavior as the interaction of individual factors, behaviors and environments. The amount of cognitive effort expended in duty can be raised either through the duration of the effort (eg, work longer) or intensity of effort (eg, work harder), or through both the duration / length and intensity of effort (Cloyd 1997).

Chang et al., (1997) found that the justification / justification represent non-financial performance incentives increase the duration / length effort. Thus, when the auditors are given an incentive to perform tasks, they are expected to increase the amount of effort (effort) to complete the task. Improved performance depends on the effort of auditors so that they are able to cope with different environments and makes the quality of a good judgment (Bonner, 1994).

From the above it can be concluded that the presence of high auditors effort to complete the task to improve the performance of auditors. Therefore, this study proposes Hypothesis 2 as follows:

$\mathrm{H} 2$ : Effort auditor positive effect on the performance of auditors.

Competence, Use of Information Technology, and Performance Auditor. The lack of direct knowledge limit the scope of the audit computer (Goldberg, 2011). When auditors have sufficient competence related to data analysis tools, IT, internal control and audit methods, they can acquire the data needed for the audit, analyzing the appropriate data, and build a complete and comprehensive automated audit. This effectively increases the completeness of the audit activities and improve the performance audit computer generated.

Hsien Wu (2017) found that competence indirectly affect the performance of internal audit through mediation effects team problem solving skills and computer audit activity. This means that with sufficient competence to audit the auditor will be able to operate a computer that allows the auditor to carry out audit work ranging from data acquisition, data analysis to preparing the audit report. With the computer audit activity performance of auditors will increase as well.

From the above it can be concluded that the presence of sufficient competence for auditors in operating a computer audit, the auditor makes it easy to carry out their duties so as to improve the performance of auditors. Therefore, this study proposes hypotheses 3 and 4 as follows: 
H3: Competence auditor positive effect on the use of Information Technology.

H4: The relationship between the auditor and the performance of the auditor's competence mediated by the use of Information Technology.

Effort Auditor, Usage of Information Technology and Performance Auditor. Payne and Curtis (2010) noted that because the auditor may not only take the decision to adopt the technology, but is also responsible for implementing the technology, the efforts made by the adoUITon of the technology may be more prominent than other IT professional auditors. Thus, Payne and Curtis (2010) argues that the effort expectancy will be associated with the behavior.

Research conducted Shamsuddin et al., (2015) proved that effort expectancy has a positive impact on the level of use of CAATs by internal auditors in Malaysia. When the auditor has a high level of effort to use information technology in the form of CAATs may improve the quality of judgment to improve the performance of audits produced. This is supported by research conducted Iskandar et al., 2012 that accountability pressure and selfefficacy positive effect with performance audit assessment through a process of high effort. Therefore,sIKAP effective against themselves against the pressures of accountability will have a high level of effort, which in turn improves the performance audit assessment.

From the above it can be concluded that when the auditor has a high effort on the use of information technology, it can improve the performance of auditors. Therefore, this study proposes hypotheses 5 and 6 as follows:

H5: Effort internal auditor positive effect on the use of Information Technology.

H6: The relationship between the auditor and the performance of the auditor's competence mediated by the use of Information Technology.

Many diagnostic hypotheses developed from, the model of this research can be seen in Figure 1 as follows:

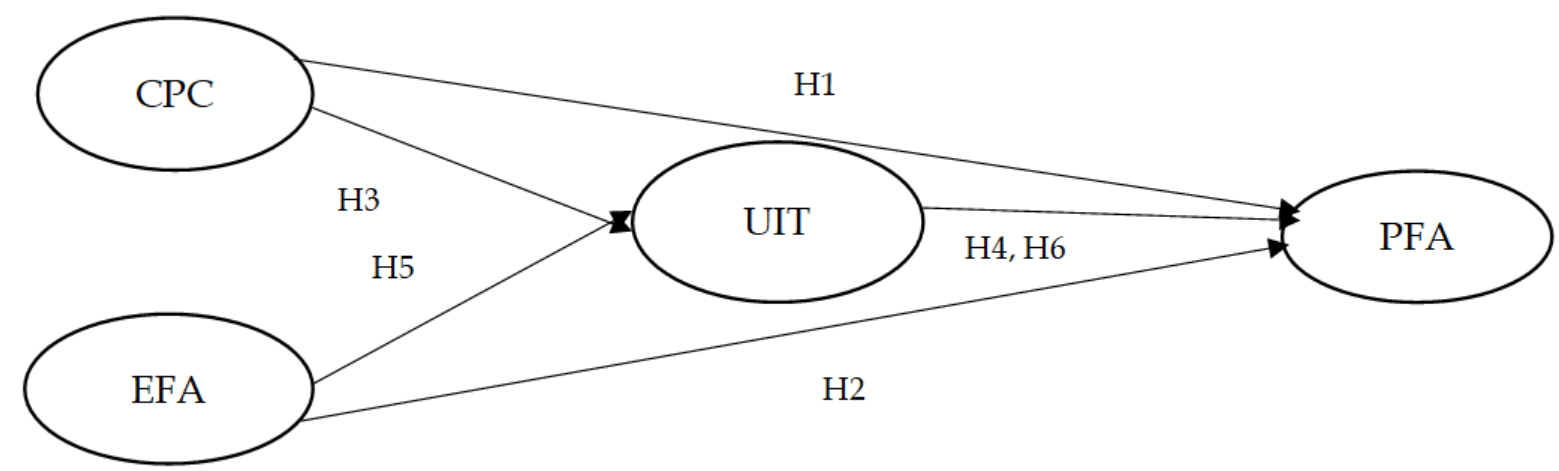

Note: CPC (competence); EFA (Effort Auditor); UIT (Use of Information Technology; PFA (Performance Auditor)

Figure 1 - Research model

\section{METHODS OF RESEARCH}

Population and Sample Research. The population used in this study were all auditors who work in Kantor Akuntan Publik (KAP) in Surabaya listed on the Directory Indonesian Institute of Certified Public Accountants (Certified) 2017 in Surabaya. The sampling technique in this study using purposive sampling method. Under this method, the criteria for determining the sample used in this study are as follows:

- Respondents in this study is the auditor who worked on KAP in Surabaya.

- Respondents were not limited to the auditor at KAP (partner, supervisors, senior, or junior auditors) so that all auditors working in the firm can be included as a respondent.

- Respondents in this study is the auditor who works for a minimum period of 1 year.

Operational Definition and Measurement of Variables. Constructs used in this study is the competence, effort auditor, the use of information technology and the performance of 
auditors. Measurement of each construct using a Likert scale of 1 to 5 which has the meaning (1) strongly disagree, (2) do not agree, (3) neutral, (4) agree, and (5) strongly agree. As for the types of variables, constructs, definitions, indicators, and the code indicator in this study are described in Table 1 below:

Table 1 - Constructs, Definition, Measurement

\begin{tabular}{|c|c|c|c|c|c|}
\hline Variable Type & Construct & Source & Definition & Indicator & $\begin{array}{l}\text { Code } \\
\text { Indicator }\end{array}$ \\
\hline \multirow{5}{*}{$\begin{array}{l}\text { Endogenous } \\
\text { Variable } \\
\text { (Dependent) }\end{array}$} & \multirow{5}{*}{$\begin{array}{l}\text { performance } \\
\text { Auditor }\end{array}$} & \multirow{5}{*}{ Esya 2008} & \multirow{5}{*}{$\begin{array}{l}\text { Working behavior of an auditor } \\
\text { in performing work tasks to } \\
\text { achieve oUITmal results }\end{array}$} & $\begin{array}{l}\text { The use of working time as effectively } \\
\text { as possible to produce the maximum } \\
\text { results of the audit. }\end{array}$ & PFA1 \\
\hline & & & & $\begin{array}{l}\text { Communication factor has an } \\
\text { important role in the execution of } \\
\text { audit engagements. }\end{array}$ & PFA2 \\
\hline & & & & $\begin{array}{l}\text { Compactness in the audit team affect } \\
\text { the speed of completion of the audit }\end{array}$ & PFA3 \\
\hline & & & & $\begin{array}{l}\text { Spending all efforts owned at the time } \\
\text { of execution of tasks to match the } \\
\text { expected goals }\end{array}$ & PFA4 \\
\hline & & & & $\begin{array}{l}\text { The use of the existing infrastructure } \\
\text { to the maximum to get the job } \\
\text { according to the standards and quality } \\
\text { expected. }\end{array}$ & PFA5 \\
\hline \multirow{8}{*}{$\begin{array}{l}\text { Exogenous } \\
\text { Variables } \\
\text { (Independent) }\end{array}$} & \multirow{8}{*}{ Competence } & \multirow{8}{*}{$\begin{array}{l}\text { Hsien Wu } \\
\text { et al., } 2017\end{array}$} & \multirow{8}{*}{$\begin{array}{l}\text { Knowledge, skills, and } \\
\text { behaviors associated with the } \\
\text { auditor conducting the audit. }\end{array}$} & $\begin{array}{l}\text { the ability to understand the } \\
\text { company's policies. }\end{array}$ & CPC1 \\
\hline & & & & $\begin{array}{l}\text { ability to develop appropriate audit } \\
\text { purposes. }\end{array}$ & CPC2 \\
\hline & & & & the ability to plan the audit planning. & CPC3 \\
\hline & & & & ability to carry out the audit work. & CPC4 \\
\hline & & & & the ability to generate audit reports. & CPC5 \\
\hline & & & & $\begin{array}{l}\text { The ability to use a computer auditing } \\
\text { software to ensure completeness of } \\
\text { data }\end{array}$ & CPC6 \\
\hline & & & & $\begin{array}{l}\text { The ability to use computers to } \\
\text { analyze the audit system audit data. }\end{array}$ & CPC7 \\
\hline & & & & $\begin{array}{l}\text { The ability to use a computer audit } \\
\text { system to perform automated audits. }\end{array}$ & CPC8 \\
\hline Variable Type & Construct & Source & Definition & Indicator & $\begin{array}{l}\text { Code } \\
\text { Indicator }\end{array}$ \\
\hline \multirow{2}{*}{$\begin{array}{l}\text { Exogenous } \\
\text { Variables } \\
\text { (Independent) }\end{array}$} & \multirow{2}{*}{ effort auditors } & \multirow{2}{*}{$\begin{array}{l}\text { Iskandar et } \\
\text { al., } 2012\end{array}$} & \multirow{2}{*}{$\begin{array}{l}\text { The amount of cognitive effort } \\
\text { expended in duty can be raised } \\
\text { either by the length of effort or } \\
\text { intensity. }\end{array}$} & $\begin{array}{l}\text { The use of more effort in the audit } \\
\text { assignment. }\end{array}$ & EFA1 \\
\hline & & & & $\begin{array}{l}\text { The use of time to complete an audit } \\
\text { assignment }\end{array}$ & EFA2 \\
\hline \multirow{6}{*}{$\begin{array}{l}\text { Exogenous } \\
\text { Variables } \\
\text { (Independent) }\end{array}$} & \multirow{6}{*}{$\begin{array}{l}\text { Use of } \\
\text { Information } \\
\text { Technology (UIT) }\end{array}$} & \multirow{6}{*}{$\begin{array}{l}\text { Hsien Wu } \\
\text { et al., } 2017\end{array}$} & \multirow{6}{*}{$\begin{array}{l}\text { Use of Information Technology } \\
\text { is the use of a software audit } \\
\text { form of CAATs }\end{array}$} & $\begin{array}{l}\text { Understanding of risk and internal } \\
\text { control related to operating processes } \\
\text { and information systems major }\end{array}$ & UIT1 \\
\hline & & & & $\begin{array}{l}\text { The use of computer audit to obtain } \\
\text { all the necessary electronic data for } \\
\text { the audit object. }\end{array}$ & UIT2 \\
\hline & & & & $\begin{array}{l}\text { The use of computers to analyze data } \\
\text { audit audit properly, make sure they } \\
\text { meet the objectives of the audit. }\end{array}$ & UIT3 \\
\hline & & & & $\begin{array}{l}\text { The use of computer audit to make an } \\
\text { automatic audit for audit objects }\end{array}$ & UIT4 \\
\hline & & & & $\begin{array}{l}\text { The use of computer audit to obtain } \\
\text { sufficient audit results and } \\
\text { appropriate. }\end{array}$ & UIT5 \\
\hline & & & & $\begin{array}{l}\text { The use of computer audit to conduct } \\
\text { ongoing audits of the goal. }\end{array}$ & UIT6 \\
\hline
\end{tabular}

Data analysis technique. The statistical method used to test the hypothesis proposed in this study is Partial Least Square (PLS) with the help of WrapPLS program. Evaluation models in PLS is done by evaluating the outer and inner models models. Outer model is a measurement model to assess the validity and reliability of the model. Outer equation model used is as follows:

$$
\begin{array}{ll}
\text { UIT }=\text { UIT.CPC UIT.EFA }+ \text { e1 }+\rho & \text { Substruktural } 1 \\
\text { PFA }=\rho \text { PFA.CPC }+P+\rho \text { PFA.EFA PFA.UIT + e2 } & \text { Substruktural } 2
\end{array}
$$

Where: $\mathrm{a}=$ constanta; $\rho=$ coefficient beta; PFA = Performance Auditor; UIT = Use of Information Technology; EFA = effort auditors; CPC = Competence; $\mathrm{e}=$ standard error. 


\section{RESULTS AND DISCUSSION}

Characteristics of Respondents. Respondents in this research that the auditor who works on Kantor Akuntan Publik (KAP). Distributing questionnaires carried out during the event Education and Training Public Accountant Certification Audit Level Pusdiklat BPK held on 13 to 17 November 2017. The questionnaires were returned a total of 61 respondents. The following is a descriUITve profile of the respondents including gender, age, years of service, position, and the last education:

Table 2 - Characteristics of Respondents

\begin{tabular}{llll}
\hline Information & Criteria & Frequency & Percentage \\
\hline Gender & Man & 36 people & $59.00 \%$ \\
& woman & 25 people & $41.00 \%$ \\
Age & amount & 61 people & $100.00 \%$ \\
& $20-25$ years & 23 people & $37.70 \%$ \\
& $26-30$ years & 14 people & $23.00 \%$ \\
Years of service & a 30 years & 24 people & $39.30 \%$ \\
& amount & 60 people & $100.00 \%$ \\
& $1-2$ years & 17 people & $27.90 \%$ \\
Office & $3-5$ years & 19 people & $31.10 \%$ \\
& > 5 years & 25 people & $41.00 \%$ \\
& amount & 60 people & $100.00 \%$ \\
& Junior Auditor & 23 people & $37.70 \%$ \\
& Senior Auditor & 27 people & $44.20 \%$ \\
Last education & supervisor & 4 people & $6.60 \%$ \\
& Audit Manager & 2 persons & $3.30 \%$ \\
& partner & 4 people & $3.30 \%$ \\
& amount & 61 people & $100.0 \%$ \\
& D3 & 1 person & $1.60 \%$ \\
& S1 & 47 people & $77.00 \%$ \\
& S2 & 12 people & $19.70 \%$ \\
& S3 & 1 person & $1.60 \%$ \\
& amount & 60 people & $100.00 \%$ \\
\hline
\end{tabular}

Based on Table 2 above shows that the auditor men dominate the sample proportion accountant who works on Kantor Akuntan Publik (KAP) in Surabaya as many as 36 people with a percentage of $59 \%$. The age of respondents mostly aged $>30$ years with a percentage of $39.30 \%$. These conditions show that the average respondent had an older age. Most of the time works respondent> 5 years and served as a senior auditor with a percentage of $41.00 \%$ and $44.20 \%$. This shows that the respondents are long worked in the Office of Public Accountant and has a long experience and competence are pretty good. While education in the past, most respondents educated as S1 with a percentage of $77 \%$.

Evaluation Measurement Model (Outer Model). Measurement model evaluation is performed to test the validity and reliability. The test results PLS stage measurement model will be presented in tables 2 and 3, as follows:

Validity test. Assessment in testing the validity can be seen from the results of the combined loading and cross loading and Variances Average Extracted (AVE), as follows in Table 3.

Table 3 shows that the variable performance of auditors, competence, effort auditor, and the use of information technology has a valid criterion by deleting some indicator which does not qualify / criteria. Overall variable with some indicators have met the following criteria loading values above 0.5 and $p$-valuenya $(<0.05)$ and the average variance extracted (AVE) above 0,50 (Hair et al., 1987; 2009). This suggests that the terms of validity of the measuring instrument are met and means that all the items of the statements used in this study could reveal something that was measured in the questionnaire.

Reliability Test. Assessment in testing the validity can be seen from the results Composite reliability coefficients, as follows in Table 4.

Table 4 shows the carry value of composite reliability coeficient of 0.618 competence, effort auditor amounted to 0.933 , use of information technology amounted to 0,812 , and the performance of the auditor amounted to 0.889 . Value Composite reliability coefficients of each construct has been qualified is worth over 0.70 . Thus, it can be concluded that the 
statements in the questionnaire is reliable because the reliability of composite value should be more than 0.70 (Hair et al., 2011). This shows that every item statement that is used will be able to obtain consistent data, which means when the statement was refiled be obtained relatively the same answer to the previous answer.

Table 3 - Validity of Test Results

\begin{tabular}{llllllll}
\hline Construct & item & PFA & CPC & EFA & UIT & P Value & AVE \\
\hline Performance Auditor (PFA) & PFA1 & $\mathbf{0 6 8 0}$ & 0.465 & 0047 & -0247 & $<0.001$ & 0,509 \\
& PFA2 & $\mathbf{0 6 4 5}$ & -0363 & -0229 & 0.279 & $<0.001$ & \\
& PFA3 & $\mathbf{0 6 9 1}$ & -0304 & 0084 & 0.275 & $<0.001$ \\
& PFA4 & $\mathbf{0 7 7 6}$ & 0.122 & .196 & -0267 & $<0.001$ & \\
& PFA5 & $\mathbf{0 7 6 6}$ & 0043 & -0123 & 0007 & $<0.001$ & \\
\hline Competence (CPC) & CPC1 & 0.187 & $\mathbf{0 7 7 7}$ & .124 & -0313 & $<0.001$ & .601 \\
& CPC2 & 0045 & $\mathbf{0 7 6 6}$ & -0124 & -0329 & $<0.001$ & \\
& CPC3 & 0,197 & $\mathbf{0 7 2 3}$ & -0131 & -0456 & $<0.001$ & \\
& CPC4 & 0099 & $\mathbf{0 7 6 3}$ & -0129 & -0155 & $<0.001$ & \\
& CPC5 & -0191 & $\mathbf{0 7 8 9}$ & -0018 & 0.534 & $<0.001$ & \\
& CPC6 & -0179 & $\mathbf{0 7 9 8}$ & -0001 & .536 & $<0.001$ & \\
\hline effort Auditor (EFA) & CPC7 & -0129 & $\mathbf{0 8 0 8}$ & 0.256 & .117 & $<0.001$ & \\
\hline Use of Information Technology (UIT) & EFA1 & .178 & 0.322 & $\mathbf{0 8 0 3}$ & -0271 & $<0.001$ & 0,645 \\
& EFA2 & -0178 & -0322 & $\mathbf{0 8 0 3}$ & 0.271 & $<0.001$ & \\
\hline UIT1 & -0018 & -0084 & -0035 & $\mathbf{0 9 1 5}$ & $<0.001$ & 0.876 \\
& UIT2 & -0014 & -0012 & -0033 & $\mathbf{0 9 4 2}$ & $<0.001$ & \\
& UIT3 & -0042 & .170 & .110 & $\mathbf{0 9 1 7}$ & $<0.001$ & \\
\hline
\end{tabular}

Source: Output WrapPLS, 2017.

Table 4 - Reliability Test Results

\begin{tabular}{lll}
\hline Variables & Composite Reliability coeficient & Information \\
\hline Competence (CPC) & 0.618 & Reliable \\
effort Auditor (EFA) & 0.933 & Reliable \\
Use of Information Technology (UIT) & 0,812 & Reliable \\
Performance Auditor (PFA) & 0.889 & Reliable \\
\hline
\end{tabular}

Source: Output WrapPLS, 2017.

Evaluation Model (Inner Model). Based on the analysis Partial Least Square for testing test structural models (inner model) with WarpPLS Program 5.0. obtained the results of the analysis as follows:

Table 5 - Evaluation Model (Inner Model)

\begin{tabular}{lll}
\hline Model & $R$-Squared & Q-Squared \\
\hline Performance Auditor (PFA) & .471 & .443 \\
Use of Information Technology (UIT) & 0.635 & 0,622 \\
\hline
\end{tabular}

Source: Output WrapPLS, 2017.

Structural model (structural model of atauinner model) is indicated by the R-squared value is recommended $>=0.02$ (Kock, 2013). Table 4 above shows that the R-Squared value for Auditor Performance of 0.471 which means that the variable competence, effort auditor, and the use of information technology to explain the performance of auditors $47.10 \%$, while the remaining $52.90 \%$ influenced by other factors which are not included in this model. While the R-Squred for the use of information technology for 0.635 which means that $63.5 \%$ variable auditor competence and effort explaining $63.50 \%$ of the use of information technology, while the remaining $36.5 \%$ is influenced by other factors that are not in this model.

Q-squaredaimed at measuring how well the predictions generated by the model construct. Based on calculations, it can be seen that the Q-squared value for the 
performance of auditors amounted to 0.445 . This shows that the model in this study has predictive relevance (match prediction) for $\mathrm{Q}$-squared value> 0 . The variable-phase variable exogenous variables such as competence, effort auditor, and the use of information technology have relevance predictive variables auditor performance. While the Q-squared value for the use of information technology for 0.622 . This shows that the model in this study has predictive relevance (match prediction) for $Q$-squared value $>0$. The variable-phase variable exogenous variables such as competence, and effort auditor has predictive relevance in the variable use of information technology.

Hypothesis testing. Hypothesis testing is done by looking at the path coefficient to determine the influence between the latent variables by means of bootstrapping can be seen in Table 5 and the resulting structural model study of WarpPLS 5.0 can be seen in Figure 2.

Table 6 - Path Coefficent

\begin{tabular}{lllll}
\hline path & path Coefficient & P-Values & standard Error & Information \\
\hline CPC $\rightarrow$ UIT & 0.615 & 0,000 & .103 & Significant \\
EFA $\rightarrow$ UIT & .284 & 0009 & .116 & Significant \\
CPC $\rightarrow$ PFA & 0.567 & 0000 & 0,105 & Significant \\
EFA $\rightarrow$ PFA & 0,211 & 0041 & 0.119 & Significant \\
UIT $\rightarrow$ PFA & .144 & 0120 & 0.122 & Not significant \\
\hline
\end{tabular}

Source: Output WrapPLS, 2017.

Note: CPC (competence); EFA (Effort Auditor); UIT (Use of Information Technology; PFA (Performance Auditor).

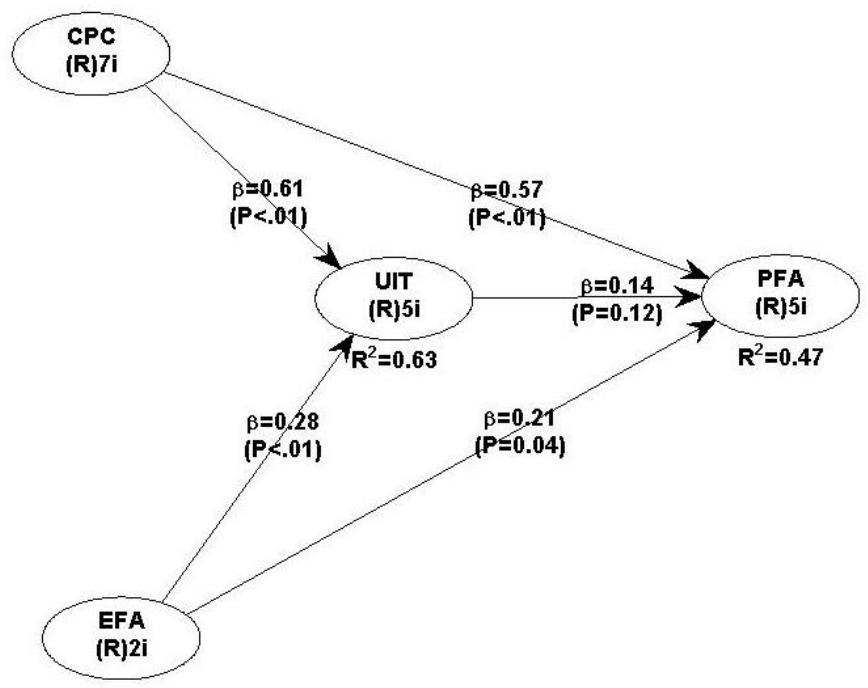

Note: CPC (competence); EFA (Effort Auditor); UIT (Use of Information Technology; PFA (Performance Auditor)

Figure 2 - Structural Model

Influence on Performance Auditor Competence. From table 6 competence hypothesis test results on the performance of auditors shows that the path coefficient of 0.615 with a pvalue $0.000<0.05$, this means that the positive effect on the competence of auditor performance means higher competence of an auditor, the higher the performance of auditors , Based on these results it can be stated that the first hypothesis is accepted. These results are consistent with research conducted by Levenson et al., 2006, Alexander \& Sanusi (2011). Zenita (2015), Afifah (2015), andHsien Wu, et al. (2017) that the competence of auditors positive effect on the performance of auditors.

High competence in self auditor, able to make the auditor believes that he can run a task on a certain level, affecting private activities towards the achievement of objectives. An auditor has a duty to constantly improve the knowledge that has been owned by the new insights that can be a maximum application of their knowledge in practice that will impact on their performance so that the quality of the resulting audit also getting better. 
Effort Influence on Performance Auditor Auditor. From Table 6 results of hypothesis testing effort on the performance of the auditor's auditor shows that the path coefficient value of 0.567 with a p-value $0.000<0.05$, this means that the effort auditor positive effect on the performance of auditors means higher effort which is owned by an auditor, the higher the performance of auditors. Based on these results it can be stated that the second hypothesis is accepted. These results are consistent with research conducted by Bonner, 1994 that the auditor's ability to cope with different environments and makes the quality of judgment depends on effort (effort) of their own to improve performance.

In performing its duties, the auditor requires a high effort. Effort can be improved through the length of effort (eg, work longer) or intensity of effort (eg, work harder). With their high effort auditor to complete the task on time according to the audit schedule that has been made, so that it can improve the performance of auditors.

Mediation on the Use of Information Technology Competencies, Performance Effort Auditor and Auditor. From Table 6 results of hypothesis testing terh competence of auditors can be enhanced either through the duration of the effort (eg, work longer) or intensity of effort (eg, work harder), adap use of information technology shows that the path coefficient value of 0.615 with a $p$-value $0.000<0.05$, this means that the competence of auditors positive effect on the use of information technology means higher competence of an auditor, the ability of the auditor in the better use of information technology. Based on these results it can be stated that the third hypothesis is accepted.

From Table 6 results of hypothesis testing effort to use information technology auditor shows that the path coefficient value of .284 with a p-value $0.009<0.05$, this means that the effort auditor positive effect on the use of information technology means higher effort issued by an auditor the auditor's ability in the use of information technology is getting better. Based on these results it can be stated that the hypothesis is accepted 5.

But the results of a test of hypothesis use of information technology to the performance of the auditor is not significant, it is reflected in the value of significance ( $p$-value) of 0120 with the value path coefficient of 0.144 . Thus the hypothesis 4 and 6 were not accepted, this means that hassociation between competence of auditors, auditors and performance auditors effort is not mediated by the use of Information Technology. The results of this study are not consistent with a study conducted by Hsien Wu (2017) found that the competence indirectly affect the performance of internal audit through mediation effects team problem solving skills and computer audit activity. AndSamhuddin (2015) proved that effort expectancy has a positive impact on the level of use of CAATs by internal auditors in Malaysia. When the auditor has a high level of effort to use information technology in the form of CAATs may improve the quality of judgment to improve the performance of audits produced.

The results of this study explained that the existence of adequate competence and a high effort for the auditor to be able to operate a computer audit that facilitate auditor in performing the audit work but with the use of information technology for audit purposes did not improve the performance of auditors. This is because the auditors who work in Kantor Akuntan Publik (KAP) does not use information technology applications such as ComputerAssisted Audit Tools And Techniques (CAATTs) to achieve the purpose of their audit. They only use the help of Microsoft Excel to do the inspection, but it also respondents in the study with an average age $>30$ years. It is also the reason why the auditors did not use information technology for audit purposes due to their age that much, they find it difficult to use information technology applications, and they chose to do the work of audit manually or using Microsoft Excel.

\section{CONCLUSION AND RECOMMENDATIONS}

Kantor Akuntan Publik is an agency that offers services such assurance audit of the financial statements, which require high quality audits. To obtain a quality audit, the auditor needs a good performance too. The results of this study indicate that the auditor's competence and effort have direct influence on the performance of auditors. And the use of 
information technology is not a mediating variable between competence and effort auditor with the auditor's performance. This is because the auditors working in the Kantor Akuntan Publik does not use a software audit information technology (CAATs) but still use microsoft excel in performing their duties.

An auditor has a duty to always develop the competencies they have. With the competence of auditors to improve their performance. Likewise with the effort issued auditors in performing their duties. The higher the effort auditor, auditor tasks can be completed on time so that the auditor's performance will be better.

This study contributes to the Kantor Akuntan Publik that the competence and effort can affect the performance of auditors. KAP thus need to include auditor training, seminar, which can increase their competence in order that the resulting performance is also getting better and the resulting audit quality is also good. And KAP needs to consider the use of information technology such as CAATs in performing its duties.

The subjects of this study was limited to the auditors working in KAP Surabaya, researchers can further expand the research subject. Use of information technology is also only limited use of the software audit form of CAATs, further research can add models Technology Acceptance Model (TAM), which can be used as a predictive tool to measure the acceptance and use of information technology, which is expected to provide results and power generalization greater for further research.

\section{REFERENCES}

1. Afifah U., Sari RN, Grace R., and Sanusi ZM 2015. The Effect of Role Conflict, Self Efficacy, Professional Ethical Sensitivity on Auditor Performance with Emotional Quotient as Moderating Variable. Procedia Economic and Finance 31: 206-212.

2. Bonner, SE 1994. A model of an audit of the effects of task complexity. Accounting, Organizations and Society 19 (3): 213-234.

3. Chang, CJ, JLY Ho, and WM Liao. 1997. The effects of justification, task complexity and experience / training on problem-solving performance. Behavioral Research in Accounting 9: 98-116.

4. Choi, J., F. Kim, J. Kim, and Y. Zang. 2010. Audit of fi ce size, audit quality and audit pricing.Auditing: A Journal of Practice \& Theory. Vol. 29. No. 1 May. Pp 73-97.

5. Cloyd, CB 1997. Performance in tax research tasks: The joint effects of knowledge and accountability. The Accounting Review 72 (1): 111-131.

6. Coderre, D. (2009). Internal Audit: Efficiency through automation (11). New Jersey: Wiley.

7. De Angelo, LE 1981. Auditor Independence, Low Balling, and Disclosures Regulation. Journal of Accounting and Economics 32. august. p. 113-127.

8. Duff. 2004. Understanding Audit Quality: The View of Auditors, Auditees and Investors.

9. Goldberg, DM 2011. General auditing for IT auditors. ISACA Journal, 3, 36.

10. Hair, JF, Ringle, CM, and Sarstedt, M. 2011. PLS-SEM: Indeed a silver bullet. Journal of Marketing Theory and Practice, Vol. 19, No. 2, pp. 139-151.

11. Hall, JA 2010. Information technology auditing and assurance.Ohio: South-Western.

12. Hsien Wu T., S. Huang Ming, Huang Yan S., C. Yen D. 2017. The Effect Of Competencies, Team Problem Solving Ability and Computer Audit on Internal Audit Activity Performance. Information System Front 19: 1133-1148.

13. Iskandar, TM, and Mohd Sanusi, Z. 2011. Assessing the Effects of Self-efficacy and Task Complexity on Internal Audit Contral Judgment, the Asian Academy of Management. Journal of Accounting and Finance, vol. 7, issue 1, pp 29-52.

14. Iskandar, TM, RN Sari, and R. Grace. Enhancing 2012. The auditors' performance The importance of motivational factors and the mediation effect of effort. Managerial Auditing Journal 27 (5): 462-476.

15. Kock, N. 2013. WarpPLS 4.0 User Manual. ScriptWarp Systems, Laredo, Texas, USA. 
16. Levenson, AR, Van der Stede, WA, \& Cohen, SG (2006). Measuring the relationship between managerial competencies and performance. Journal of Management, 32 (3), 360-380.

17. Locke, E., and Latham, G. 1990. A Theory of Goal Setting and Task Performance. New York, NY: Prentice Hall.

18. Locke, EA 1997. The motivation to work: what we know. Advance in Motivation and Achievement 10: 375-412.

19. Payne, EA, \& Curtis, MB 2010. Can the uni fi ed theory and use of Technology ofacceptance help us understand the adoUITon of computer-aided audit techniques by auditors? Working paper: University of Louisville and the University of North Texas.

20. Minister of Finance Regulation No. 17 / PMK.01 / 2008.

21. Robbins, SP 2006. The Organization of al behavior. Singapore: Prentice Hall.

22. Shamsuddin A., Rajasharen L., D. Maran, Ameer MFM, and Muthu PM 2015. Factors Influencing Usage Level Of Computer Assisted Audit Techniques (CAATS) By Internal Auditors In Malaysia. Proceeding - Kuala Lumpur International Business, Economics and Law Conference 6, Vol. 1.

23. Spencer, LM, \& Spencer, PSM (1993). Competence at work models for superior performance. New York: Wiley.

24. Sun, CM (2012). From CAATTs adoUITon to continuous auditing systems implementation: an analysis based on theories of organizational routines. MIS REVIEW: An International Journal, 17, 59.

25. Law No. 5 of 2011 on Public Accountant.

26. Wang, Y., Lo, HP, \& Yang, Y. (2004). The constituents of core competencies and firm performance: evidence from high-technology firms in China. Journal of Engineering and Technology Management, 21 (4), 249-280.

27. Zenitaa R., Saria RN, Grace R., and J. Said 2015. The Effect of Information Literacy on Managerial Performance: The mediating Role of Strategic Management Accounting and the Moderating Role of Self Efficacy. Procedia Economics and Finance 31: 199-205. 